\title{
IMPROVING CREDIT PROTECTION ANALYSIS METHODS REPORTS OF MAIN AGRICULTURAL ENTERPRISES
}

\author{
Yuliia Aleskerova ${ }^{1}$, Tetiana Mulyk ${ }^{2}$, Lidiia Fedoryshyna ${ }^{3}$ \\ Vinnytsia National Agrarian University, Ukraine
}

\begin{abstract}
The purpose of the article is to improve the methodology for analysing credit support for the reproduction of fixed assets of agrarian enterprises. Various techniques have been developed to analyse the effectiveness of the formation of fixed assets and the process of their reproduction. Among them, the application of such types of analysis as horizontal and vertical (quantitative analysis of the structure of fixed assets and its changes), analysis of return on assets, capital intensity and profitability, indicators of extensive and intensive loading are widespread. Less applicable are calculations of various coefficients, such as the rate of retirement, renewal, increase in fixed assets.). Methodology. There are several approaches to analysing the effectiveness of the process of reproduction of fixed assets. A number of domestic scholars distribute such indicators to groups: natural and valuable. Natural includes all the technical and economic performance of engines, machines, performance indicators of cattle, etc. Among the highlights are indicators of economic, sectoral efficiency, and indicators of economic efficiency. Results. Determining the efficiency of the loan support for the reproduction process involves the creation of a system of indicators that, by the structure and in aggregate, reflect the degree of efficiency of the use of the loan. Indicators that are used today to assess the effectiveness of using credit support, have fundamental disadvantages, which makes it problematic for their practical application. Practical implications. Thus, some of them do not have a sufficiently significant theoretical justification, the same indicators have different names, are unsuccessful from the logical point of view, do not adequately reflect the needs of industry practices, others - when testing in the current accounting information, it is expedient to improve them. Value/originality. The application of the analysis of reproduction of fixed assets will allow receiving growth of economic indicators of activity of agricultural enterprises on the basis of ensuring the continuous process of financing production by economically grounded sources of working capital formation, one of which is short-term bank credit.
\end{abstract}

Key words: methodology, analysis, credit support, fixed assets, agriculture, reproduction.

JEL Classification: F65, G21, P34, Q12

\section{Introduction}

In order to properly formulate recommendations for improving the methods and forms of credit support for the reproduction of fixed assets of agricultural enterprises, a detailed analysis is required. The method of analysis of credit support is quite a capacious concept and concerns the effectiveness of both credit support and the process of reproduction of fixed assets. Therefore, we can talk about the need for a double formulation of the problem and the allocation of its micro and macro levels.

The specifics of credit and credit support are studied, as a rule, with the application of an integrated approach to studying their substance, based on the dialectical method of cognition. This involves the use of various aspects of the analysis of the essence of the object under study and allows you to highlight the levels of study of the essence of the research object. In such aspects, we have identified the economic essence and content of credit, loan support, peculiarities of credit support for the reproduction of agricultural assets, which reveals the structure of the section.

At present, the economy has identified a number of topical issues that are important for the sustainable functioning and development of the agrarian sector of the economy. Priority ones include theoretical and methodological issues related to improving

\footnotetext{
Corresponding author:

${ }^{1}$ Department of Finance, Banking and Insurance, Vinnytsia National Agrarian University.

E-mail: tuv@email.ua

${ }^{2}$ Department of Analysis and Statistics, Vinnytsia National Agrarian University.

E-mail:mulyk@vsau.vin.ua

${ }^{3}$ Department of Analysis and Statistics, Vinnytsia National Agrarian University.

E-mail: fedorishina@i.ua
} 
the efficiency of the system of financial and credit relations in the industry, in particular, credit provision. The state of the problem under study has certain attainment and achievements. The results of research generalizations of world experience and national practice that allow determining the problems of different forms of participation of banks in financing the reproduction of resource potential, in particular, of fixed assets are relevant. In addition to traditional lending to the needs of the industry, there are used special investment projects, the participation of banks as investors, the formation of units for financing innovative activity, use of leasing and mortgage operations.

The purpose of this work is the improvement of methods of analysis of credit supply of the reproduction of main agricultural enterprises.

The basis of the research is the dialectic method of recognition, the principle of historicism, used to study the profit as an economic category in the course of the historical development of society. The following common scientific methods were used to determine the tasks: analysis, synthesis, induction, deduction, comparison, grouping, analogy, systematization.

\section{Economic crisis effects on consumer behaviour}

For the analysis of the efficiency of forming the fixed assets and process of their recreation, different methodologies are presently worked out. Among them, there are widespread applications of such types of analysis as horizontal and vertical (quantitative analysis of the structure of the fixed assets and her changes), analysis of return on capital, capital intensity and profitability, indexes of the extensive and intensive loading. Settling of different coefficients belong to less applied, such as a coefficient of leaving, updating, increase of the fixed assets. In addition, efficiency of the use of the fixed assets is very exactly represented by the indexes of the use of technical equipment on the grouped descriptions that allow determining the influence of different factors on the indexes of efficiency (methods of analysis of factor: method of absolute differences, method of chain substitution and others like that) (Harrington, Wilson, 1989). The described methodologies are examined in different train aid from an economic analysis in the special literature.

Problems in assessing the effectiveness of using financial and credit resources are first of all raised in their relationship with the financial performance of agricultural enterprises. Other important criteria include increasing the production potential, expanding the scope of the reproduction process, increasing the volume and quality of production.

\section{Differences in consumer spending behaviour among age groups}

According to researchers, it is precisely the inadequate quality of existing methods for analysing creditworthiness, the validity of approaches to calculating the parameters of financial security, making it difficult for a realistic assessment of the provision of credit resources by enterprises in the industry. It is emphasized that at the present stage of development of the economy of agriculture, it requires significant support for the processes of reproduction of resource potential.

Among the basic factors of the economic growth of agriculture, an important place belongs to the state of resources of industry, in particular, to the fixed assets. From the great number of sources of their recreation important is the credit providing. The objective need to use a loan for the reproduction of fixed assets is due to the specifics of the reproductive process in the field, which has a seasonal nature. On this time, in terms of low profitability of agricultural enterprises, low investment attractiveness of industry, considerable downstream, harmony in work of most basic resources, the credit providing of recreation of the fixed assets is the real source of forming of material base of agricultural production.

The credit providing of agricultural enterprises is the effective event of the exit of the economy from a crisis. It especially topically for a period when an economy of the industry is in a slump and stabilizing and development is broken over the lack of the clear foreground programs of their development.

There are a few approaches to the analysis of the efficiency of the process of recreation of fixed assets. The row of domestic scientists distributes such indexes on groups: natural and cost.

All techno-economic indexes of work of engines, machines behave to natural, indexes of the productivity of cattle and others like that. Among a cost distinguish the indexes of pertaining to the national economy, branch efficiency, and indexes of economic efficiency.

As additional indicators, it is recommended to use the cost of production; the amount of gross and net income per unit of land; return on assets and productivity, calculated on the basis of gross income; the payback period of capital investments, etc.

Determination of the efficiency of the credit providing of reproductive process envisages the creation of systems of indexes that by a structure and in totality represented the degree of efficiency of drawdown. On the modern stage of development of credit relations, there is a practically absent analysis of the efficiency of the drawdown from the point of view of its influence on the results of productive-financial activity of agricultural enterprises on the whole and recreation of the fixed assets in particular. The reason for this according, to researchers (Contino, 1996), is 
the lack of comprehensive methodological approaches to determining the effectiveness of lending developed in the light of the specifics of financial and economic activity of agricultural borrowers.

To improve the organization of the crediting process of reproduction of fixed assets, "it is necessary to find out the level of its efficiency, using the system of cost and physical indicators" (Contino, 1996).

Indicators that are used today to assess the effectiveness of using credit support have fundamental disadvantages, which makes it problematic for their practical application. Thus, some of them don't have sufficiently significant theoretical substantiation, the same indicators have different names, are unsuccessful from the logical point of view, do not adequately reflect the needs of industry practices, others - when testing in the current accounting information, they find expediency to improve them. The proposed methods contain an insufficient number of indicators with a weak link between them. They unilaterally and without proper completeness characterize the efficiency of using loans in the enterprise (Forgionne, 1986).

That is, according to the research carried out, it is the systemic approach to the study that the validity and appropriateness of the practical application of the developed methods for determining the effectiveness of the use of credit support depend on.

As it was investigated, the reduction of the solvency of agricultural producers led to the suspension of the investment process, the reduction of the funding, technical, and energy equipment production.

Therefore, there is a need to determine the economic efficiency of ensuring the reproduction of fixed assets, including at the expense of credit resources (Contino, 1996).

However, at the current stage, the development of scientifically substantiated proposals to improve the definition of credit support for reproduction of fixed assets of agricultural enterprises is not sufficient.

For the achievement of the put aim, it is necessary to solve the next tasks:

- to estimate the modern state of the credit providing of recreation of the fixed assets of industry;

- to define tendencies and influence of factors that determine their development;

- to generalize methodical principles of determination of credit potential of agricultural enterprises.

Regarding credit potential, we have investigated and found that in this category (its interpretation) distinguish loan support bank - excess reserves of the bank or banking system and enterprises - the possibility of the additional attraction of credit resources (Aleskerova, 2016).

Modern methods of assessing creditworthiness enable an assessment of the current financial situation of agricultural enterprises and their immediate future
(Aleskerova, 2016). However, most of the enterprises need to assess the amount of loans that are needed to finance costs and capital investments.

As already noted by Russian researchers "developed a methodology for assessing the minimum requirement of the economic entity in working capital, as well as the need for reproduction of outside negotiable assets, adjusted to secure the loan agreement from the side of the potential borrower own property" (Todosiychuk, 2007). They also recognized that the assessment of needs of the enterprise in lending non-current assets is a priority in determining the credit potential and in general its value depends on the formed optimal structure of working capital. For this the following calculation is proposed: the additional need for sources of credit is calculated based on the recoverable value of fixed assets minus equity and long-term loans and loans. If the indicator is positive - there is a shortage of own funds for reproduction.

Taking into account the current national practice of using the method developed by researchers (Forgionne, 1986), the following criteria are taken into account. Determining the effectiveness of using credit support requires the availability of indicators that would objectively reflect the degree of use of credit in the enterprise and the methodology for their calculation.

In connection with our research, the methodology of efficiency involves also taking into account the efficiency of attracting credit resources for the formation of production capacity in fixed assets.

For example, rather a detailed analysis of current methods of credit security efficiency was conducted by Wilson (Harrington, Wilson, 1989). It is established that "from the standpoint of the number of indicators, which determines the credit performance in the proposed methodological approaches, it is possible to distinguish two main directions. One group of scientists focuses on finding a single indicator of assessing the effectiveness of the loan; the other, on the contrary, proves the need for a system of indicators".

\section{Survey methodology}

Thus, it can be assumed that, at the present stage, a system of indicators has been formed that unites groups for analysing the efficiency of reproduction (use) of fixed assets and analysing the efficiency of credit sources. In the first case, the swingeing majority of researchers have stopped on the key elements of the methodology of determination of the efficiency of recreation of the use of the fixed assets after directions:

1) provision of fixed assets of enterprises;

2) state of fixed assets;

3) efficiency of the use of fixed assets.

In the second case, the question is about the determination of project efficiency of sources of the credit providing, after directions: 
1) market of sources of credit support for reproduction of fixed assets;

2) availability of credit support for agricultural enterprises;

3) efficiency of programs and sources of credit provision.

Given these groups, we have formed Table 1, which lists the typical indicators and their calculation formula for the efficiency of the process of reproduction of fixed assets.

Thus, the efficiency of the use of fixed assets is determined by a set of closely interconnected indicators that quantitatively express the ability of an agricultural enterprise to make productive use of material resources in terms of fixed assets in order to ensure the continuity of the reproduction process. Each individual indicator involved in the methodological approach characterizes one of the parties, according to a certain criterion, the influence of the use of fixed assets on the efficiency of production.

According to the researchers, the generalized criterion of the efficiency of functioning and reproduction of basic productive assets is the expressed ratio of the gross domestic product to the average annual cost of the main productive assets. According to researches, in 1990 this indicator for Ukraine was $42.0 \%$, in 1995 - 16.8\%, in $1998-14.4 \%$. That is, its reduction is observed.

Table 1

Methodology for analysing the effectiveness of credit support for the reproduction of fixed assets

\begin{tabular}{|c|c|c|}
\hline Index & Calculation & Ingredients \\
\hline \multicolumn{3}{|c|}{ Security by main means } \\
\hline Capacity & $\mathrm{C}=\mathrm{F} / \mathrm{V}$ & $\begin{array}{l}\text { C - capacity } \\
\text { F - the average annual cost of the main productive assets } \\
\text { V - volume of production }\end{array}$ \\
\hline Fundamental arsenal & $\mathrm{F} / \mathrm{a}=\mathrm{F} / \mathrm{R}$ & $\begin{array}{l}\text { F/a - fundamental arsenal } \\
\text { F - average annual cost of the fixed productive assets } \\
\mathrm{R} \text { - number of workers }\end{array}$ \\
\hline Technical armament & $\mathrm{T} / \mathrm{a}=\mathrm{P}_{3} / \mathrm{R}$ & $\begin{array}{l}\mathrm{T} / \mathrm{a} \text { - technical armament } \\
\mathrm{F}-\mathrm{a} \text { cost of the fixed productive assets is on an operation } \\
\mathrm{R} \text { - a number of workers is on an operation }\end{array}$ \\
\hline \multicolumn{3}{|l|}{ State of fixed assets } \\
\hline Wear factor & $\mathrm{Wf}=\mathrm{Aw} / \mathrm{F}$ & $\begin{array}{l}\text { Wf - wear factor } \\
\text { Aw - amount of wear } \\
\text { F- initial cost of fixed assets }\end{array}$ \\
\hline Coefficient of fitness & $\mathrm{Cf}=\mathrm{Rv} / \mathrm{F}$ & $\begin{array}{l}\text { Ff - fitness factor } \\
\text { Rv- residual value } \\
\text { F- initial cost of fixed assets }\end{array}$ \\
\hline Coefficient of updating & $\mathrm{Rr}=\mathrm{Fr} / \mathrm{Ff}$ & $\begin{array}{l}\mathrm{Rr} \text { - refresh rate } \\
\mathrm{Fr}-\text { - the cost of receiving fixed assets } \\
\mathrm{Ff} \text { - cost of funds at the end of the year }\end{array}$ \\
\hline Coefficient of leaving & $\mathrm{Er}=\mathrm{Fd} / \mathrm{Ff}$ & $\begin{array}{l}\text { Er- exit rate } \\
\text { Fd- the cost of disposal of fixed assets } \\
\text { Ff - the cost of fixed assets at the beginning of the year }\end{array}$ \\
\hline Coefficient of increase & $\mathrm{Gr}=(\mathrm{Fr}-\mathrm{Fd})$ & $\begin{array}{l}\mathrm{Gr} \text { - growth rate } \\
\mathrm{Fr} \text { - the cost of receiving social funds } \\
\mathrm{Fd} \text { - pay the disposal of fixed assets }\end{array}$ \\
\hline Index of height & $\mathrm{Ih}=\mathrm{Ff} / \mathrm{Ff}($ beginning of the year $)$ & $\begin{array}{l}\text { Ih - index of height } \\
\mathrm{Ff} \text { - cost of funds at the end of the year } \\
\mathrm{Ff} \text { - the cost of fixed assets at the beginning of the year }\end{array}$ \\
\hline Coefficient of stability & $\mathrm{Cs}=(\mathrm{Fa}-\mathrm{Fd}) / \mathrm{F} \Pi$ & $\begin{array}{l}\text { Cs - coefficient of stability } \\
\text { Fa - the cost of fixed assets at the beginning of the year } \\
\text { Fd - the cost of disposals of fixed assets }\end{array}$ \\
\hline \multicolumn{3}{|c|}{ Efficiency of the use of fixed assets } \\
\hline Return on assets & $\mathrm{Ra}=\mathrm{V} / \mathrm{F}$ & $\begin{array}{l}\mathrm{f} \text { - return on assets } \\
\mathrm{V} \text { - volume of products } \\
\mathrm{F} \text { - average annual cost of the fixed assets }\end{array}$ \\
\hline Profitability & $\mathrm{R}=\mathrm{P} / \mathrm{F}$ & $\begin{array}{l}\mathrm{R} \text { - profitability } \\
\mathrm{P} \text { - annual profit } \\
\mathrm{F} \text { - average annual cost of the fixed assets }\end{array}$ \\
\hline $\begin{array}{l}\text { A sum of profit per } 1 \text { hryvnia } \\
\text { of fixed assets }\end{array}$ & Ро3 $=\mathrm{P} / \mathrm{F}$ & $\begin{array}{l}\text { Po3 - a sum of profit per } 1 \text { hryvnia of fixed assets } \\
\text { P - annual profit } \\
\text { F - average annual cost of fixed assets }\end{array}$ \\
\hline
\end{tabular}


It is this indicator that can objectively reflect the role of major productive assets in increasing the efficiency of social production.

A methodological approach to determining the effectiveness of the use of fixed assets - a tool for financial and economic analysis, which is used to strengthen management functions. It quantitatively expresses the results of the influence of the use of fixed assets on the efficiency of the agricultural enterprise and, on this basis, provides an objective and complete information management system for a retrospective, operational, and prospective analysis and the adoption of economically sound management decisions.

The application of the analysis of reproduction of fixed assets will allow receiving growth of economic indicators of activity of agricultural enterprises on the basis of ensuring the continuous process of financing production by economically grounded sources of working capital formation, one of which is short-term bank credit.

To objectively assess the effectiveness of the use of fixed assets as a complex organizational and technical complex that has a defined socio-economic form, several groups of criteria have been identified that reflect this performance both in relation to the economy as a whole and at the level of the individual enterprise (Todosiychuk, 2007).

When considering the relationship between investment and the reproduction of major productive assets, many researchers (Aleskerova, 2016) paid attention to the link between the level of inflation, the size of bank interest and the directions of flows of investment resources. They noted that "high borrowing interest limits or even eliminates the possibility of obtaining bank loans especially for the restoration of fixed assets.

This is not the only negative finding of the influence that raises the costly credit for the sphere of material production.

In this regard, it seems reasonable to propose the orientation of the NBU to the level of average profits in the production sector. Such an event, along with a reduction in tax pressure can play a significant role in replenishing the resources of production enterprises and will contribute not only to overcoming the crisis phenomena but also to further economic development" (Aleskerova, 2008).

Considered criteria for evaluating the effectiveness of reproduction/functioning of the main productive assets along with the advantages and have certain disadvantages. First, not all of them are accurately displayed in quantitative terms. Second, each of them reflects only one aspect of the problem and does not give a complete picture of the state, change the efficiency of use and reproduction.

Based on such a scheme, recommendations were developed to improve the methods and forms of financial and credit support for innovative activities of small enterprises. On the basis of a comprehensive analysis of the directions of state financial support for the development of enterprises including their innovation activities in terms of providing the main means, and the need for indirect measures of financial support has been identified.

In studies of another author (Contino, 1996) to assess the attractiveness of enterprises, the index of viability index (Ii) was proposed. This indicator takes into account the index of current activity (Ica) and the index of estimation of the innovative potential of the enterprise (Iip) and is their sum.

The index of viability of current activities will vary according to a number of factors, which firstly will determine features of the enterprise operation, depending on the size, experience of its activities and the costs of implementing innovations; and secondly, they will be able to evaluate at different stages of its activity from the very beginning to possible liquidation.

The proposed index can be used to understand the logic of the main factors of enterprise development, to quantify their impact, to understand what factors and in what proportion it is necessary for the enterprise to mobilize to increase the efficiency of the activity.

To reflect the activity of the innovation activity of the enterprise, the same author (Forgionne, 1986) provided an index of innovation potential (Iip), which is characterized by a share of the cost of innovation activities ( $\mathrm{Cin})$ in the total cost $(\mathrm{Ci})$. The increase of this index testifies to the increase of innovative potential of the enterprise. It is established that this indicator should tend to one approach, which in modern conditions is due to the necessity not only to predict but also to increase the amount of resources that will be directed to innovative activity.

The researchers also noted that the necessary condition for choosing the most effective lines of credit support for reproduction of fixed assets is the creation of a unified methodological and informational basis for the study of the state and prospects of innovative economic development. In the methodology, it is possible to predict the possibility of evaluating the effectiveness of the investment project. For this purpose, various authors suggest the following set of indicators (Table 2).

Consequently, the method of the effectiveness of credit support for the reproduction of fixed assets should take into account the composition, sources of formation, perspective directions of use to increase production volumes.

In economic research on the constancy of credit provision, it is important to study stochastic (correlation) relationships in economic analysis.

Stochastic connections (Contino, 1996) are characterized by an approximation, uncertainty. They are detected only on average in a significant number of objects observed. Each value of the factor index 
Table 2

Estimation of the efficiency of the innovative project

\begin{tabular}{|c|c|c|c|}
\hline Indexes & Used name & Characteristic & Notes \\
\hline $\begin{array}{l}\text { Net discounted } \\
\text { income }\end{array}$ & $\begin{array}{l}\text { Net Present Value, } \\
\text { NPV }\end{array}$ & $\begin{array}{l}\text { This indicator characterizes the excess of total } \\
\text { cash receipts related to the implementation of } \\
\text { the investment project over the total cost of it } \\
\text { and is calculated as the amount of discounted } \\
\text { net payments during the estimated time period. }\end{array}$ & $\begin{array}{l}\text { If NPV }>0 \text {, then the profitability of the project } \\
\text { is higher than the norm given by the discount } \\
\text { factor. At NPV }<0 \text { the project profitability } \\
\text { below the norm and from the project should } \\
\text { be discarded. When comparing projects, the } \\
\text { advantage should be given, in other equal terms, } \\
\text { to a project with a high NPV value. }\end{array}$ \\
\hline $\begin{array}{l}\text { Profitability } \\
\text { index }\end{array}$ & $\begin{array}{l}\text { Profitability Index, } \\
\text { PI }\end{array}$ & $\begin{array}{l}\text { Characterizes the relative "return on the } \\
\text { project" on the funds invested in it and is } \\
\text { calculated as the ratio of NPV to the current } \\
\text { cost of investment in the project. }\end{array}$ & \\
\hline $\begin{array}{l}\text { Internal rate of } \\
\text { return }\end{array}$ & $\begin{array}{l}\text { Internal Rate Return, } \\
\text { IRR }\end{array}$ & $\begin{array}{l}\text { The internal rate of return of the project shows } \\
\text { the level of return on investment costs invested } \\
\text { in the project and is calculated as a discount } \\
\text { rate, at which the net discounted income } \\
\text { (NPV) of the project is zero. }\end{array}$ & $\begin{array}{l}\text { The decision to invest in a project is approved if } \\
\text { the IRR is higher than the interest rate on long- } \\
\text { term loans. The IRR is used to determine the } \\
\text { terms for lending to creditors since it calculates } \\
\text { the interest rate that can be paid without risk of } \\
\text { undermining the project's liquidity. } \\
\text { Since the IRR is determined on the basis of } \\
\text { current prices, it must be compared with the real } \\
\text { value of capital. If the nominal interest rate on } \\
\text { loans is d and inflation is D percent during the } \\
\text { discount period, then the real value of capital } \\
\text { will be d-D and, in particular, with this value, } \\
\text { you should compare the IRR. }\end{array}$ \\
\hline Payback period & Payback Period, PB & $\begin{array}{l}\text { The payback period of the project characterizes } \\
\text { the period of time necessary to recover } \\
\text { the investments invested in the project } \\
\text { at the expense of the proceeds from its } \\
\text { implementation and is calculated as a period } \\
\text { of time, in which the net discounted project } \\
\text { income (NPV) is zero. }\end{array}$ & $\begin{array}{l}\text { In the practice of evaluating investment projects, } \\
\text { a simple and discounted indicator of payback } \\
\text { period is used. }\end{array}$ \\
\hline $\begin{array}{l}\text { Simple profit } \\
\text { margin }\end{array}$ & $\begin{array}{l}\text { Simple Rate Return, } \\
\text { SRR }\end{array}$ & $\begin{array}{l}\text { The criterion is calculated according to } \\
\text { the formula and shows, which part of the } \\
\text { investment costs is reimbursed in the form of } \\
\text { profit within one planning interval. Comparing } \\
\text { the calculated value of the profit margin with a } \\
\text { minimum or an average level of profitability, the } \\
\text { investor may come to the conclusion that it is } \\
\text { expedient to further analyse the projects. }\end{array}$ & \\
\hline
\end{tabular}

(argument) may correspond to a significant number of performance indicators (functions). Stochastic dependence is a differential equation which component is functions that have random values.

For our study, the attraction of credit resources in the reproduction of fixed assets gives rise to differences in the growth of profits at various enterprises even on other equal terms. This is due to the fact that the level of profit depends on the action of the factors that interact in the complex.

The fact that the various factors interact optimally depends on the degree of influence of each of them on the magnitude of the effective indicator.

To measure the degree of influence of each factor on the level of the effective indicator, factor analysis is used.

Necessary conditions for applying correlation analysis are:
1) the presence of a sufficiently large number of observations on the magnitude of the investigated factor and performance indicators (or the dynamics for the current year in the aggregate of homogeneous objects);

2) the investigated factories should have a quantitative dimension and reflect one or another source of information.

Use of correlation analysis allows solving the following tasks:

- to determine the change in the effective indicator under the influence of one or several factors, how much the value of the result will change when the factor is changed to 1 ;

- establish the relative degree of dependence of the result.

Some author (Contino, 1996) state that "a prerequisite for choosing the most effective directions 
of innovation and structural policy is the creation of a unified methodological and informational basis for studying the state and prospects of innovative economic development".

At present, there is a sufficiently wide range of methods for solving tasks of assessing the effectiveness of investment projects and their sources. Each of them provides some opportunities for a comprehensive analysis of alternatives and the selection of the best of them by one or another criterion. When analysing with the help of a mathematical apparatus, it is possible to observe a rather broad scope of their interaction and complementarity in terms of models and research tools.

With regard to public funding, the main criterion for selecting investment projects claiming state support is the maximum budget efficiency. Although there is a certain legal basis for replenishing profitable and linking the cost of the investment budget, its functioning is ineffective.

According to a number of authors (Cocheo, 1996), their main elements are the analysis of financial flows of costs and outputs, the calculation of the internal rate of effectiveness, the accounting of risk, as well as the separate elements of the mechanism of reproduction and credit provision.

The question arises about the use of methods of financial mathematics and simulation in the competitive selection of investment projects claiming state support on the criterion of the highest return on hryvnia investments.

\section{Findings}

By the aim of creation of a mathematical model of the credit providing of support of reproductive process in agriculture, in particular, in terms of fixed assets, is the assessment of investments in the competitive selection of investment projects claiming state funding, the development of computational algorithms and computer implementation, the conduct of computational experiment for real systems.

Later, the use of indicators is determined, which allows us to draw conclusions about the interdependence of such important parameters of the enterprise's activity as profitability of sales, profitability of assets, the coefficient of reinvestment of profits, and also the ratio of borrowed and equity capital, which enables to combine the investment strategy of an enterprise with a financial strategy (Cocheo, 1996).

The level of lending, the volume of required loans depends on a number of factors but the most significant among them is the share of own funds in the total amount of production costs. The correlationregression analysis method was used to determine the degree of correlation between the share of own funds and the volume of obtaining loans by agricultural enterprises.

\section{Conclusions}

Thus, the current state of the credit system of Ukraine is characterized by a number of shortcomings:

1) low mobilization of credit institutions by monetary resources and excess of demand for credit resources over their offer;

2) lack of reliable credit facilities and high risk of lending, which results in lending institutions placing mobilized resources mainly in the money market and credit risks offset by high-interest rates;

3) functioning of the lending market mostly for universal banks. Specialized financial and credit institutions are only being formed, while the issue of quantitative development of credit institutions is acute.

To overcome these shortcomings, the following measures must be taken:

1. Create favourable economic and legal conditions for investing in deposits and developing a settlement system, restoring the confidence of depositors in lending institutions.

2. Facilitate the development of a guarantee and insurance system, as well as secondary mortgage lending and debt markets, which will provide organizational stability to the credit system to respond to crisis trends.

3. To develop the systems of registration and appraisal of collateral objects, as well as centralized information systems.

4. To apply economic privileges to credit institutions that lend to the real sector of the economy, while limiting speculative operations and promoting the development of specialized lending institutions.

\section{References:}

Aleskerova Yu.V. (2008) Analiz stanu ta efektivnosti kreditnogo zabezpechennya vidtvorennya osnovnikh zasobiv silskogospodarskikh pidpriemstv [Analysis of the status and effectiveness of credit support for reproduction of fixed assets of agricultural enterprises]. Oblik i finansi APK, vol. 3, pp. 125-129.

Aleskerova Yu.V. (2016) Problemi vprovadzhennya bankivskikh kreditnikh innovatsiy v agrarniy sferi [Problems of introduction of bank credit innovations in agrarniy sphere]. Prichornomorski ekonomichni studii, vol. 9, nn. 1, pp. 100-103.

Todosiychuk Yu.V. (2007) Vydy ta formy kreditiv u zabezpechenni vidtvorennya osnovnikh zasobiv [Types and forms of loans to ensure the reproduction of fixed assets]. Ekonomika APK, vol. 12, pp. 98-101.

Cocheo S. (1996) Banking's New Life on Lease, ABA Banking Journal. 11: 40-48.

Contino R.M. (1996) Handbook of Equipment Leasing. A Deal Maker's Guide, 2nd ed. - New York: AMACOM: 205.

Forgionne G.A. (1986) Quantitative Decision Making, Publishing Company: 296.

Harrington D.R., Wilson B.D. (1989) Corporate Financial Analysis, 3rd ed. Richard D. Irwin, Inc.: 190. 